\title{
Dampak Wifi Bagi Pemuda Terhadap Sosial Keagamaan Desa Cibubukan Aceh
}

\author{
Sarkawi \\ STAI Syekh Abdur Rauf Aceh Singkel \\ sarkawisingkil@gmail.com
}

\begin{abstract}
Technological advances have brought so many changes, these changes are not only in the world of education, including the world of business, culture and social society, technological advances are so fast entering all comers, including the internet which is part of the development of these technologies. Data packages are not a problem in order to be able to access the internet and social media such as facebook, whatsapp, messenger, twitter and others, it can almost be said that the internet is now a necessity, lately several village governments provide free wifi networks for theirpeople, including villages fuss. This research is a field research, which is based on the facts and facts found, the data collection tools are observation, interviews, questionnaires and library materials. Questionnaires were distributed to 40 people as samples and the results were managed and analyzed. The author found several facts in the field, some of which can be concluded, after the availability of free wifi access, youth began to be preoccupied with their respective gadgets, and the culture of Maghrib Koran has begun to disappear, in social matters that previously helped each other and worked hand in hand, now starting being indifferent, so that the socio-religious youth after the existence of the internet, especially free wifi, experienced a decline and decline.
\end{abstract}

Keyword: Wifi, Youth, Religious Social

Abstrak. Kemajuan teknologi sangat banyak membawa perubahan, perubahan tersebut bukan hanya dalam dunia pendidikan, termasuk dunia usaha, budaya dan sosial kemasyarakatan, kemajuan teknologi begitu cepat masuk ke seluruh pelosok, termasuk internet yang merupakan bagian dari perkembangan teknologi tersebut. Paket data tidak menjadi persoalan demi bisa mengakses internet dan bermedia sosial seperti facebook, whatsapp, messenger, twitter dan lainnya, hampir dapat dikatakan internet saat ini merupakan sebuah kebutuhan, akhir-akhir ini beberapa pemerintahan desa menyediakan jaringan wifi secara bebas bagi masyarakatnya, termasuk desa cibubukan. Penelitian ini merupakan penelitian lapangan, yang didasarkan atas realita dan fakta yang ditemukan, alat pengumpulan datanya adalah Observasi, wawancara, penyebaran angket dan bahan kepustakaan. Angket disebar kepada 40 orang sebagai sampel dan hasilnya dikelola dan dianalisis. Penulis menemukan beberapa fakta dilapangan diantaranya yang dapat disimpulkan, pasca tersedianya wifi bebas akses, pemuda mulai disibukkan dengan gadget masing-masing, dan budaya magrib mengaji sudah mulai hilang, dalam hal sosial yang sebelumnya saling membantu dan bahu membahu, kini mulai bersikap acuh tak acuh, sehingga sosial keagamaan pemuda pasca adanya internet terlebih wifi gratis mengalami penurunan dan kemerosotan.

Kata Kunci. Wifi, Pemuda, Sosial Keagamaan 


\section{PENDAHULUAN}

Kemajuan Teknologi Komunikasi dan informasi sangat memberi makna dan arti bagi perubahan dunia, baik dari sisi pendidikan, ekonomi, pemerintahan, dan perkembangan dakwah, kemudahan yang dirasakan oleh lapisan masyarakat dalam mengakses informasi dan juga bidang keilmuan yang dapat diakses di internet dari dampak kemajuan teknologi tersebut sangat banyak membantu masyarakat, bahkan di tengah pandemi covid-19 yang melanda dunia yang menyebabkan harus menjaga kerumunan tidak berpengaruh secara umum dalam menjalankan aktifitas sebagaimana biasanya, sebagai contoh pemuda masih tetap bisa belajat dari rumah atau istilah yang sering disebut belajar daring, pemerintah dalam menyelesaikan administrasi dan mengirim laporan juga sangat banyak terbantu dengan internet tersebut, namun dalam penggunaan internet tersebut pengguna harus menyediakan paket data untuk dapat menggunakannya.

Pertumbuhan dan perkembangan teknologi informasi dan komunikasi di era globalisasi saat ini membuat banyak perubahan bagi kehidupan manusia saat ini, dan menghadirkan keuntungan dan manfaat yang luar biasa bagi setiap individu, serta membawa dampak yang positif dan negatif dalam dunia digital. Dampak positif dari adanya teknologi adalah proses data dan informasi yang menjadi tulang punggung dunia informasi dapat dilakukan dengan cepat, akurat dan tepat waktu sedangkan dampak negatifnya adalah timbul kejahatan penyelewengan dari penggunaan perangkat tersebut. (Hermalia dan Khairan 2019) Hal ini juga diperkuat oleh pernyataan Bustamin, dkk tentang dampak generasi muda terhadap perkembangan teknologi dan era globalisasi. Generasi muda saat ini yang juga dikenal dengan generasi milenial disatu sisi dituntut untuk mengikuti arus perkembangan zaman, namun disisi lainnya terdapat dampak negatif yang mempengaruhi generasi milenial termasuk di dalamnya adalah para pelajar. (Bustamin, et.all, 2020)

Sementara bagi pelajar pada waktu tertentu diberikan subsidi paket data oleh pemerintah melalui kemendikbud, sehingga tidak ada alasan tidak ada paket data, begitu juga dengan pemerintah desa dapat mengalokasikan anggaran untuk membayar paket data demi kepentingan pemerintahan, namun seiring kemajuan dan perkembangan zaman, dalam rangka menyukseskan administrasi pemerintahan untuk memenuhi kebutuhan data internet, dalam membantu pekerjaan di pemerintahan desa, pemerintah dengan segala kebijakannya mengalokasikan dana untuk penyediaan Jaringan Wifi di desadesa, tidak terkecuali desa cibubukan juga memiliki jaringan wifi. 
Keberadaan wifi di kantor desa cibubukan untuk penyelenggaraan pemerintahan desa, sepenuhnya dibayar langganan biaya data dengan anggaran desa, sehingga pelaksanaan administrasi tidak menjadi terhambat, bahkan desa juga memberikan layanan kebebasan menggunakan jaringan bagi seluruh lapisan masyarakat sehingga masyarakat dapat menikmati dan tidak menjadi penghalang ketika paket data di gadget tidak tersedia, begitu juga pelajar, mahasiswa dan pemuda yang memerlukan paket data dapat merapat kekompleks kantor desa untuk dapat menyambungkan ke jaringan wifi, sehingga dapat mengakses informasi, data, dan belajar melalui internet secara langsung.

Kehadiran wifi pada sisi positif memberikan manfaat besar kepada masyarakat desa cibubukan, apalagi dengan pandemi covid 19, acara kebangsaan, keagamaan, dan penampilan lainnya sering dibatasi pengunjung, namun pemerintah sering melakukan siaran langsung atau live streaming, untuk dapat menghindari kerumunan dan masyarakat tetap dapat menyaksikannya dari rumah masing-masing. Kenyataan ini tentu dapat membawa dampak perubahan sosial dalam kehidupan masyarakat. Beberapa penelitian tentang bahaya Internet sudah banyak dilakukan, namun lebih spesifik tentang Dampak wifi bagi pemuda terhadap sosial keagamaan di desa cibubukan sejauh ini belum penulis temukan diantara penelitian tentang Internet atau teknologi yang ada hubungannya dengan penelitian ini akan penulis tuliskan dibawah ini.

Dalam penelitian Anang (2019) menjelaskan Setiap manusia selama hidup pasti mengalami perubahan- perubahan. Perubahan dapat berupa pengaruhnya terbatas maupun luas, perubahan yang lambat dan ada perubahan yang berjalan dengan cepat. Perubahan dapat mengenai nilai dan norma sosial, pola-pola perilaku organisasi, susunan lembaga kemasyarakatan, lapisanlapisan dalam masyarakat, kekuasaan dan wewenang, interaksi sosial dan sebagainya. Perubahan- perubahan yang terjadi pada masyarakat merupakan gejala yang normal (Anang, 2019)

Berbicara masalah perubahan sosial, biasanya selalu terkait dan berkisar pada dampak baik atau buruknya suatu perubahan sosial, dampak baik dan buruknya masuknya suatu teknologi baru atau sistem kelembagaan baru yang disebarkan kepada masyarakat (Achmad Hidir, 2009). Termasuk juga kepada pemuda dan bila hal ini tidak bisa dipilah akan dapat membawa dampak yang tidak baik dalam perkembangan karakter pemuda kedepan

Menurut Dewi (2011) penggunaan internet memiliki dampak terhadap pola perilaku masyarakat di perkotaan. Temuan studi menunjukkan bahwa 
telah terjadi evolusi penggunaan internet, dari penggunaan untuk fungsi sederhana (komunikasi) menjadi penggunaan de-ngan fungsi yang spesifik. Temuan studi lainnya menunjukkan bahwa pengguna internet merupakan masyarakat yang berpendidikan tinggi (well educated) dan mampu secara finansial (well financed). Studi tersebut juga menunjukkan dampak yang teridentifikasi akibat penggunaan internet secara intensif dapat dibagi berda-sarkan tiga kriteria, yaitu pola pergerakan, pola aktivitas dan implikasinya terhadap interaksi sosial. (Noviana Dewi, et.all, 2016: 223)

Tetapi internet itu tidak hanya mendatangkan efek positif bagi penggunanya, internet juga memiliki efek positif yang cukup berbahaya bagi pengguna nya. Peran internet dalam mempromosikan berita atau gambar vulgar telah merusak tradisi dan moral (Nuzuli, et all., 2021). Internet yang seharusnya menjadi tempat kita menggali informasi dan ilmu dari seluruh belahan dunia telah di alih fungsikan sebagai tempat mengakses situs situs yang tak sepantasnya di akses. (Sofita, et. all, 2019: 40)

Desa cibubukan merupakan sebuah desa yang ada di kecamatan Simpang Kanan Aceh Singkil, daerahnya yang merupakan pedalaman dan terletak di Daerah Aliran Sungai, Kehidupan Sosial Keagamaan masyarakat desa cibubukan sebenarnya ramah, sederhana dan bersahaja. Dalam kajian sosiologi secara umum, Orang desa sangat memegang teguh prinsip gotong-royong dan musyawarah untuk mufakat dalam kehidupan sehari-harinya. Antara satu warga dan warga lain merupakan ikatan keluarga yang harus dibantu dan ditolong. Oleh karena itu, prinsip gotong royong, tolong-menolong mewarnai sebagai bagian tradisi dan adat turun-temurun.

Perkembangan teknologi ternyata berdampak kepada masyarakat desa cibubukan serta memberikan warna terhadap perubahan sosial keagamaan terlebih-lebih bagi pemuda desa cibubukan, akan tetapi hal tersebut merupakan masih hipotesis, untuk memberikan gambaran yang pasti diperlukan penelitian tentang dampak wifi tersebut terhadap pemuda dalam sosial keagamaan didesa cibubukan, yang dimana fokus penelitian dalam tulisan ini, (1) bagaimana keadaan sosial masyarakat pasca adanya wifi gratis di desa cibubukan, (2) bagaimana perhatian orang tua dan tingkat kepedulian terhadap sosial keagamaan para pemuda di desa cibubukan.

Penelitian ini merupakan penelitian lapangan, dimana sebelumnya penulis telah melakukan observasi dan juga dengan mengadakan pengamatan langsung di tengah tengah kehidupan sosial masyarakat, sebelum melakukan penulisan, penulis mengumpulkan data-data baik data kepustakaan maupun data 
lapangan, data lapangan dimaksud dengan menyebar angket kepada 40 orang responden sebagai sampel dalam penelitian ini untuk dijadikan data awal serta wawancara dengan tokoh masyarakat yang dianggap dapat menunjang kebutuhan data penelitian untuk dilakukan kajian setelah mengumpulkan data untuk mengambil kesimpulan. Sehingga dapat memberikan hasil penelitian yang akurat dan pasti.

Sementara responden yang akan penulis ambil dalam penelitian ini, responden sebagai sampel sebanyak 40 orang, serta tokoh masyarakat, tokoh agama dan juga pemuda desa cibubukan, sehingga dapat menambah informasi yang lebih akurat.

\section{HASIL DAN PEMBAHASAN}

\section{Profil Masyarakat Desa cibubukan}

Desa cibubukan salah satu desa tertua di Kecamatan Simpang Kanan Aceh Singkil, desa ini berada di pinggiran Sungai, masyarakat desa cibubukan pada dasarnya bekerja sebagai petani, yang menghasilkan bahan pangan untuk kebutuhan hidup keluarga, desa ini jauh dari kebisingan perkotaan, jarak desa cibubukan dengan Pusat Kecamatan mencapai 3 KM, desa ini terdapat sebuah Sekolah Dasar dan juga Balai Pengajian untuk fasilitas pendidikan anak-anak. Penduduk desa cibubukan $100 \%$ beragama Islam. Kehidupan masyarakat desa cibubukan sangat bersahaja dan sederhana, pada dasarnya masyarakat desa Cibubukan hidup penuh kedamaian dan sangat peduli antar sesama.

Dalam kehidupan bersosial, masyarakat desa cibubukan, selalu mengedepankan kebersamaan saling gotong royong dan bahu membahu, budaya dan adat istiadat begitu terus dipertahankan dengan seksama, sebagai contoh ketika ada kegiatan pesta, musibah, masyarakat dan pemuda selalu hadir dan saling peduli serta saling membantu menyukseskan kegiatan tersebut, begitu juga dengan keagamaan, budaya mengaji ba'da maghrib dari dulu sudah menjadi kebiasaan, walaupun terjadi kemunduran pasca masuknya listrik dan televisi ke desa ditahun 2000 an, kegiatan keagamaan yang terus digalakkan seperti Berjanji ( Membaca Shalawat Syarafal Anam) Dalailul Khairat dan juga bahkan kegiatan belajar Fardu Ain bagi kalangan orang tua, apalagi pemerintah Aceh menugaskan seorang Da'I didesa ini sehingga kegiatan keagamaan masih dilestarikan.

Masyarakatnya yang jauh dari pengaruh Perkembangan kehidupan modern membuat kedamaian yang semakin sejuk, akses jalan pada tahun 90 an hanya menggunakan transportasi perahu untuk belanja ke pasar seminggu 
sekali, namun seiring perkembangan jaman, digalakkannya pembangunan infrastruktur yang merata termasuk ke desa cibubukan, pada awal tahun 2000an diterobosnya jalan pengerasan dan mulai pada tahun 2002 lampu masuk desa, sekitar tahun 2005 mulai masuk televisi, dan akses jalan melalui air mulai menurun karena transportasi darat sudah dimanfaatkan, dan puncaknya pada tahun 2015 hampir $100 \%$ masyarakat sudah memiliki kendaraan bermotor jenis Sepeda Motor.

Dalam bidang usaha yang dulunya masyarakat sebagai petani sawah, secara bertahap beralih ke bidang perkebunan, masyarakat beralih ke perkebunan Kelapa Sawit, apalagi banyaknya masuk investor di bidang perkebunan kelapa sawit di Aceh Singkil membuat masyarakat tergiur dengan hasilnya sehingga lahan yang awalnya sebagai lahan persawahan kini berganti menjadi lahan perkebunan, hampir 90\% lahan tersebut sudah kering karena dimanfaatkan menjadi perkebunan kelapa sawit.

\section{Keadaan Pemuda Pasca Masuknya Wifi Desa cibubukan}

Pemuda merupakan generasi yang diandalkan dalam sebuah pembangunam dan perubahan kedepan, karena pemuda merupakan estafet perjuangan, sehingga pemuda perlu dijaga dan dibina untuk bisa menjadi manusia yang bermoral dan beretika, agar tidak mudah terpemngaruh dengan hal-hal yang tidak baik, masa pemuda merupakan masa-masa yang paling menjanjikan, sehingga keberadaan pemuda telah banyak di abadikan dalam alqur'an Surat Al-kahfi ayat 13:

"Sungguh mereka adalah pemuda-pemuda yang beriman kepada Tuban mereka, dan

Kami tambah pula petunjuk. untuk. mereka"

Banyak kisah pemuda beriman diabadikan dalam Al-qur'an seperti Ashabul Kahfi, Kisah Yusuf yang kokoh dalam keimanan ketika di goda Zulaikha, kisah Ismail seorang pemuda yang siap disembelih demi mendekatkan diri kepada Allah, yang kesemuanya mendapat karunia lebih ketika mereka mampu melalui cobaan dengan kekuatan imannya. Pemuda itu sendiri merupakan penerus cita-cita perjuangan bangsa yang sekaligus sebagai sumber insan bagi pembangunan (Abdul Gafur, 1982: 14)

Kehadiran internet pada dunia teknologi membuatnya seakan sudah menjadi kebutuhan rutinitas dalam kehidupan manusia selama ini. Hal tersebut terlihat dari berbagai tujuan sasaran penggunaan internet, baik sebagai media informasi, media jejaring sosial dan lain sebagainya (Muhammad Rizal, Muhammad Iqbal). Teknologi internet juga berdampak terhadap perilaku dan 
kehidupan generasi masa kini. Anak-anak masa kini begitu akrab dengan internet melalui berbagai perangkat gawai, seperti: komputer, laptop, tablet, handphone, smartphone, dan perangkat sejenisnya. Kehidupan mereka mulai dari; bermain, berkomunikasi, bergaul, menyalurkan hobby, dan aspek-aspek lainnya tidak terlepas dari teknologi internet. (Saifuddin, Chalim, E Oos M Anwas, 2018: 33-34)

Para ahli sepakat bahwa penggunaan internet layak untuk mendapatkan perhatian serius ada kecenderungan semakin hari semakin meningkat dan cenderung berlebihan, dan dalam jangka panjang dapat mengakibatkan adanya gangguan mental seperti gangguan anti sosial, gangguan kecemasan, dan gangguan stress pada penggunanya (Siti Nurina Hakim, et. all, 2017: 313-314)

Perkembangan dunia teknologi informasi mulai menyentuh masyarakat pedesaan mulai adanya Handphone, android terus berkembang membuat kehidupan masyarakat semakin meningkat, mudahnya informasi dari internet membuat seluruh lapisan masyarakat juga memanfaatkannya, walaupun membutuhkan Data internet yang menambah biaya pengeluaran dalam keseharian, internet dengan segala fiturnya saat ini mulai menjadi sebuah kebutuhan bagi sebagian masyarakat desa cibubukan, yang menambah semangat berusaha untuk dapat mengisi paket data, ternyata tidak hanya sampai disitu, pemerintah dengan kebijakannya membuat Jaringan Wifi di Desa menambah kesempurnaan kehidupan modern bagi masyarakat desa cibubukan.

Kemajuan teknologi komunikasi yang ada saat ini dapat menjangkau seluruh pelosok wilayah tanpa terkecuali, karena sarana prasarana yang tersedia tersebut lebih efektif dan efisien digunakan(Joko Isdianto, 2010: 2), begitu juga ditambah alat bantu wifi yang merupakan sebuah perangkat internet tanpa penggunaan kabel, dengan wifi pengguna dapat mengakses internet dengan mudah dan unlimited dan jaringannya juga juga begitu cepat, penggunaan wifi ini tidak hanya sebatas administrasi, tetapi juga sebagian dapat dimanfaatkan oleh publik untuk keperluan akses internet, Perkembangan pemanfaatan Teknologi Wi-Fi telah tumbuh begitu pesat karena akses dan transaksi melalu internet menjadi sesuatu yang sangat penting(Rio Priantama, tt, hlm.23) Hampir dapat dikatakan bahwa internet sebagai fasilitas yang kaya akan informasi mendekati kebutuhan bagi manusia apalagi bagi pemerintahan dan lembaga pendidikan, lebih-lebih pada masa pandemi covid yang melanda dunia. 
Manfaat wifi adalah untuk dapat menghubungkan pada jaringan internet, dimana dalam penggunaan media internet, sangat banyak manfaat yang dapat dipetik, dari sisi pendidikan, dari sisi sosial, bisa terjalin silaturahmi, bisa saling bertukar informasi, begitu juga dalam pelaksanaan meeting, dan sangat banyak lainnya yang dapat diambil manfaatnya dari internet tersebut. Penggunaan internet ini juga seiring dengan perkembangan zaman dan perubahan kehidupan.

Seiring dengan pertumbuhan anak dan perkembangan zaman, banyak remaja muslim sekarang yang akhlaq dan perilakunya menyalahi aturan agama Islam. Mereka banyak yang tidak memikirkan apakah dampak yang ia lakukan akan menimbulkan banyak kebaikan atau madharatnya. Di era globalisasi ini, dunia dipenuhi dengan berbagai macam teknologi yang canggih. Mulai dari teknologi yang menguntungkan sampai teknologi yang dapat menjerumuskan generasi muda ke dalam jurang kehinaan, (Misbahul Wani, 2019, h. 73)

Untuk Melihat Keadaan Pemuda desa cibubukan pasca wifi dapat penulis gambarkan sebagai berikut;

\section{Waktu Penggunaan Wifi}

\begin{tabular}{|c|c|c|c|c|}
\hline $\begin{array}{c}\text { Waktu } \\
\text { Penggunaan }\end{array}$ & Siang & Malam & Siang Malam & Jumlah \\
\hline Jumlah & 8 & 25 & 7 & 40 \\
\hline Persentase & $20 \%$ & $62,5 \%$ & $17,5 \%$ & $100 \%$ \\
\hline
\end{tabular}

Informasi tersebut memberikan bahwa penggunaan malam hari lebih dominan pada pengguna wifi di desa cibubukan, sementara untuk melihat kebiasaan yang sudah mulai tertinggal pasca dihadapkan pada wifi tersebut, dapat penulis gambarkan sebagai berikut:

Apakah Pemuda Masih terlibat Dalam Kegiatan Keagamaan

\begin{tabular}{|c|c|c|}
\hline Alternatif Jawaban & Responden & Persentase \\
\hline Ya & 27 & $67,5 \%$ \\
\hline Tidak & 0 & $0 \%$ \\
\hline Kadang-Kadang & 13 & $32,5 \%$ \\
\hline Jumlah & 40 & $100 \%$ \\
\hline
\end{tabular}

Secara umum, dapat dipastikan bahwa Kegiataan Keagamaan masih melibatkan pemuda, akan tetapi terjadi penurunan pasca adanya wifi dan jaringan internet di desa cibubukan. 


\section{Dampak Wifi Bagi Pemuda Desa cibubukan}

Adanya wifi yang tersedia membuat masyarakat terbantu dalam segi Paket Data, tidak dapat dipungkiri paket data untuk dapat mengakses internet merupakan suatu keharusan, dan saat ini kebutuhan internet dalam memanfaatkan Media Sosial seperti Facebook, Whatsapp dan lainnya sudah mulai hampir seluruh penduduk negeri menggunakannya, tidak terkecuali masyarakat desa cibubukan, akan tetapi untuk melihat dampak wifi bagi Pemuda terhadap Kehidupan Sosial Keagamaan perlu dilakukan penelitian, agar tidak menerka-nerka dalam berasumsi.

Teknologi komunikasi dapat mempengaruhi aspek sosial dan budaya suatu kelompok masyarakat seperti dunia maya (website). Jika seseorang sudah merasa terlalu asyik dengan teknologi seperti di dunia maya, biasanya akan menghabiskan waktu selama berjam-jam karena hanya berinteraksi dengan seorang teman atau kenalan. Kemajuan teknologi informasi dan komunikasi sekarang memberikan pengaruh tersendiri pada budaya di Indonesia (Salman Yoga S, 2018: 33). Kenyataan ini sebenarnya hampir merata diseluruh pelosok negeri tidak bisa dihindarkan, karena pada dasarnya ketika ada suatu perkembangan yang menyentuh kelompok masyarakat, akan berpengaruh pada perubahan sosial.

Seorang remaja ketika mereka dihadapkan pada perubahan teknologi baru pertama-tama mereka dituntut untuk dapat menerima dan menyesuaikan diri dengan teknologi tersebut. Kedua, perubahan teknologi mempunyai suatu tujuan untuk memenuhi kebutuhan masyarakat. Akan tetapi perubahan teknologi ini mempunyai dampak yang positif dan negatif terhadap perilaku remaja. Perubahan teknologi yang berdampak pada interaksi sosial para remaja menyebabkan ketidakseimbangan antara norma lama dengan keadaan saat ini sehingga dibutuhkan adanya kontrol sosial dari keluarga ataupun lingkungan terdekat mereka agar tetap terjadi Jurnal Analisis Sosiologi 3 (1) 101 keseimbangan antara nilai dan norma lama dengan kondisi sosial saat ini dengan tujuan untuk mempertahankan integrasi dalam masyarakat (Ana Puji Astuti, 2014: 100-101)

Setelah melakukan pengamatan, menyebarkan angket dan wawancara dengan beberapa masyarakat desa cibubukan tentang Dampak Wifi bagi pemuda tersebut Penulis mendapatkan berbagai informasi di antaranya:

1.Dampak Positif

Dalam penelitian ini, penulis ingin mencari tanggapan responden tentang dampak positif pasca adanya wifi di Desa cibubukan, terlebih-lebih untuk 
remaja yang merupakan usia yang sedang asik-asinya menggunakan internet, untuk melihat dampak positif dalam bidang pendidikan, dapat dilihat dari tabel berikut:

Tabel 1 Apakah Wifi digunakan untuk Belajar

\begin{tabular}{|c|c|c|}
\hline Alternatif Jawaban & Jumlah & Persentase \\
\hline Ya & 12 & $30 \%$ \\
\hline Tidak & 28 & $70 \%$ \\
\hline \multicolumn{2}{|c|}{ Jumlah } & $100 \%$ \\
\hline
\end{tabular}

Dari hasil angket diatas, hanya 12 orang (30\%) penggunaan wifi sebagai sarana fasilitas dalam mencari bahan pembelajaran sedangkan sisanya sebanyak 28 orang $(70 \%)$ memberikan jawaban tidak

Sementara dalam pandangan masyarakat dan tokoh bahwa dampak positif keberadaan wifi desa cibubukan dapat dilihat dari hasil wawancara penulis dengan salah satu perangkat desa sebagai berikut:

"Kami selaku pengurus desa memberikan akses internet melalui jaringan wifi sebagai bentuk dukungan kami kepada masyarakat yang memerlukan penggunaannya, begitu juga pemuda yang kami libat selalu ramai datang wilayah kantor desa hanya keperluan internet, tentunya sangat berarti bagi mereka" ('wawancara)

Hasil wawancara tersebut menunjukkan bahwa peduli pada masyarakat, namun bila ditarik dari hasil angket sebelumnya hyanya $30 \%$ yang memanfaatkan untuk pembelajaran, dengan demikian terdapat manfaat dan mudharat dalam penggunaan internet tersebut.

2.Dampak negatif

Keadaan lokasi sekitaran kantor desa terus dipenuhi oleh pengguna internet, keperluan pengguna sangat beragam, dari mulai facebook, mengakses informasi, membuka email, mendownload video, membuka youtube dan juga bermain game secara online, hal ini berdasarkan wawancara penulis dengan salah satu masyarakat di sekitar kompleks Kantor Desa.

"Sekitar kantor desa terus dipenubi oleh masyarakat, lebih-lebih pada malam hari mulai pukul 19.00 sampai dengan pukul 02.00 yang memanfaatkan jaringan wifi untuke mengakeses internet, dengan kebutuhan berbeda-beda, ada yang main game, nonton youtube, facebook dan lain-lain"'wawancara).

Disamping itu, penulis juga melakukan wawancara bagaimana keadaan sosial pemuda desa cibubukan setelah adanya wifi, sebagai berikut: 
"Pasca masuknya internet sampai di pelosok desa, sikap masyarakat lebib-lebih usia remaja secara bertahap mulai acub tak acuh, duduk berdampingan namun tidak berkomunikasi, karena disibukekan dengan aktivitas gadget masing-masing, hampir bisa dikatakan, saling tukar informasi antar sesama, cerita pekerjaan, cerita usaha dan lainnya"'wawancara).

Dari hasil wawancara tersebut, pengaruh perubahan sosial para pemuda bukan disebabkan wifi, akan tetapi masuknya internet, sehingga penulis beranggapan hal tersebut tidak ada kaitannya dengan wifi, akan tetapi hasil wawancara penulis dengan salah satu tokoh pemuda desa cibubukan memberikan respon, perubahan tersebut lebih meningkat setelah adanya jaringan wifi yang begitu bebas dan terbuka untuk di akses, berikut hasil wawancara penulis dengan tokoh pemuda cibubukan

"Perubahan sosial masyarakat dikalangan pemuda kian meningkat, setelab adanya wifi yang bebas akses, karena sebelum adanya wifi, ada dua penghalang pemuda lebih-lebih usia remaja dalam menggunakan internet, salah satunya jika pengguna dari rumah, maka orang tua berperan dalam memantau dan mengawasi, namun kalau diluar rumah, ketika tidak ada kegiatan lain, orang tua tidak dapat membatasi, begitu juga sebelum adanya wifi, pemuda masih yang malas sekalipun masib semangat untuk berusaha paling tidak menutupi kebutuban paket datanya, ketike wifi tersedia, tidak ada lagi menjadi persoalan, dan babkan anak-anak remaja yang begadang sampai pukul 02.00 babkan sampai pukul 03.00 secara umum pasti bangunnya juga kesiangan" (wawancara).

Sementara berdasarkan angket yang penulis sebar sebanyak 40 responden memberikan tanggapan tentang keberadaan remaja dalam penggunaan media internet desa cibubukan dapat dilihat dalam tabel berikut:

\begin{tabular}{|c|c|c|}
\hline Penggunaan & Jumlah & Persentase \\
\hline Media Sosial & 11 & $27,5 \%$ \\
\hline Game Online & 20 & $50 \%$ \\
\hline Lainnya & 9 & $22,5 \%$ \\
\hline \multicolumn{2}{|c|}{ Jumlah } & $100 \%$ \\
\hline
\end{tabular}

Dari hasil angket diatas, sebanyak 11 atau 27,5 \% Responden memberikan jawaban penggunaanya untuk Media Sosial seperti Facebook, Whatsapp dan messenger, dan untuk game online sebanyak 20 orang atau 50 $\%$ dan sedangkan lainnya seperti Download Video, membaca berita dan termasuk mencari bahan pembelajaran hanya 9 Orang 22,5\%, sedangkan 
melihat usia pengguna internet menurut hasil wawancara penulis dengan salah satu masyarakat desa cibubukan sebagai berikut:

"Pengguna wifi untuk mengakses internet didominasi usia 12 - 18 Tahun, sisanya usia $S D$ dan Kalangan Mahasiswa, hampir rata-rata yang memanfaatkan internet di kantor desa adalah usia Sekolah"'wawancara).

Dari hasil wawancara diatas, menunjukkan bahwa usia Sekolah lebih banyak memanfaatkan wifi tersebut, dan hampir dapat dipastikan pengawasan orang tua sudah mulai menurun pasca adanya jaringan wifi tersebut di desa cibubukan.

Kemudian untuk melihat sisi keagamaan masyarakat khususnya pemuda pasca tersedianya wifi tersebut, penulis juga menggali informasi dari responden yang hasilnya memberikan jawaban sebagai berikut:

"Perkembangan zaman tidak dapat terbendung, sebelum listrik masuk desa, para pemuda disibukekan dengan aktivitas yang bermanfaat, dari mulai mengaji Al-qur'an ba'da maghrib, terlibat dalam sosial keagamaan, dan kegiatan lainnya seperti ikut shalat jama'ah, menyemarakkan hari-hari besar Islam, namun saat ini hal tersebut sudah mulai jarang ditemui, (wawancara)

Hasil wawancara tersebut diatas menunjukkan bahwa keberadaan wifi membawa dampak menurunnya semangat keagamaan para pemuda, disebabkan kelalaian dan keasyikannya dengan media sosial yang merupakan hal yang baru bagi mereka.

\section{KESIMPULAN}

Kehadiran internet secara umum dapat memberikan perubahan dunia, masyarakat yang memanfaatkan dengan sedemikian rupa dapat terbantu, begitu juga fasilitas yang disediakan desa memberikan arti bagi masyarakat dan juga pemuda, karena dapat membantu mereka dalam memenuhi kebutuhan paket data, akan tetapi secara spesifik kehadiran wifi di desa cibubukan berdasarkan penelitian ini ditemukan hasil bahwa kehadiran wifi bukan awal dari menurunnya sosial keagamaan pemuda, akan tetapi sejak kehadiran internet sudah mulai terjadi penurunan, namun setelah adanya wifi gratis, hal tersebut lebih meningkat.

Sementara sebagian orang tua yang juga terlena dengan perkembangan dunia teknologi serta disebabkan faktor lingkungan yang sudah mulai berkembang dan maju, perhatian kepada anak-anak terjadi penurunan, karena gadget saat ini hampir dianggap sebagai sebuah kebutuhan dasar bagi masyarakat. 


\section{DAFTAR REFERENSI}

Ana Puji Astuti \& Anike Nurmalita RPS. (2014) Teknologi Komunikasi dan Prilaku Remaja, Jurnal Analisa Sosiologi. 3 (1)

Bustamin, B., Islami, M. H., Mirdad, J., \& Burda, H. (2020). Strengthening Muslim Millenal Generations in Era Disruption. Proceeding iain Batusangkar, 1(1)

Cahyono, Sugeng, Anang. (2019). Pengaruh Media Sosial Terhadap Perubahan Sosial Masyarakat di Indonesia, Jurnal Publiciana 9 (1).

Hermalia Wita, Rahmat Musfikar, \& Khairan AR. (2019) Analisis pengaruh layanan wi-fi terhadap peningkatan kepuasan dan motivasi belajar mahasiswa uin ar-raniry, Cyberspace: Jurnal Pendidikan Teknologi Informasi, 3 (2).

Hidir, Achmad. (2009), Antropologi Budaya Perspektif ekologi dan perubahan budaya, Riau; Pusat Pengembangan Pendidikan Universitas Riau.

Isdianto, Joko. (2010) Dampak Teknologi Komunikasi terbadap Aspek Sosial Dalam Suatu Perubahan Sosial http://repository.ut.ac.id/2270/1/ fisip201003. Jurnal

Jamaluddin, Nasrullah, Adon. (2015) Sosiologi Perdesaan, Bandung: Pustaka Setia.

Noviana Dewi, \& Stefanus Khrismasagung Trikusumaadi. (2016), Bahaya Kecanduan Internet dan Kecemasan Komunikasi terhadap Karakter Kerja Sama pada Mahasiswa, Jurnal Psikologi 43 (3).

Nuzuli, A. K., Natalia, W. K., \& Adiyanto, W. (2021). Tinjauan Pelanggaran Kode Etik Jurnalistik dalam Pemberitaan Prostitusi Online di Surabaya. Jurnal Warta ISKI, 4(1).

https://doi.org/https://doi.org/10.25008/wartaiski.v4i1.108

Priantama, Rio. Efektifitas Wifi dalam menunjang proses pendidikan bagi lembaga perguruan tinggi, Jurnal clound information. 1(1).

Saifuddin Chalim \&E. Oos M. Anwas. (2018) Peran Orangtua dan Guru dalam Membangun Internet sebagai Sumber Pembelajaran Jurnal Penyuluban, 14 (1). 
Siti Nurina Hakim, Aliffatullah Alyu Raj, \& Dara Febrian Chita Prastiwi. (2017) Remaja dan Internet, Prosiding SEMNAS Penguatan Individu di Era Revolusi Informasi.

Wani, Misbahul. (2019) Pemuda dalam al-qur'an dan as-sunnah: pemuda islam yang berkualitas tidak lepas dari pendidikan orang tua yang totalitas, Jurnal al-drikera, 13, (1)

Yoga S, Salman. (2018) Perubahan Sosial Budaya Masyarakat Indonesia Dan Perkembangan Teknologi Komunikasi Jurnal Al Bayan 4 (1).

Yunia Ruwanna Sofita, Sartika, Meitiana Audya \& Ali Ibrahim. (2019), Pengaruh Internet Terhadap Interaksi Sosial Pada Mahasiswa Universitas Sriwijaya, Positif: Jurnal Sistem dan Teknologi Informasi, 5 (1).

\section{Wawancara}

Ainal Basri. (2021, September 05) Personal Interview

Naung, Raja. (2021, Agustus 15) Personal Interview.

Sahminuddin. (2021, Agustus 21) Personal Interview

Sasliadi. (2021, September 06), Personal Interview 